\title{
INDUÇÃO E ANÁLISE BIOQUÍMICA DE CALOS OBTIDOS DE SEGMENTOS FOLIARES DE Coffea arabica L., CULTIVAR RUBI
}

\author{
CÍNTIA GUIMARÃES DOS SANTOS ${ }^{1}$ \\ RENATO PAIVA ${ }^{2}$ \\ PATRÍCIA DUARTE DE OLIVEIRA PAIVA ${ }^{3}$ \\ EDILSON PAIVA ${ }^{4}$
}

\begin{abstract}
RESUMO - Conduziu-se este trabalho com o objetivo de estudar o efeito de 2,4-D e BAP na indução da formação de calos originados de segmentos foliares de plântulas de Coffea arabica L., cv Rubi, obtidas in vitro, a partir da cultura de embriões, determinar sua curva de crescimento e analisar bioquimicamente, mediante determinação dos teores de proteínas totais, açúcares redutores e padrão proteíco. Segmentos foliares inoculados em meio desprovido de reguladores ou na presença de BAP em condições isoladas não apresentaram formação de calos. A produção máxima de calos é
\end{abstract}

TERMOS PARA INDEXAÇÃO: Coffea arabica, indução de calos, padrão protéico.

obtida utilizando-se $1,0 \mathrm{mg} \mathrm{\textrm {L } ^ { - 1 }}$ de 2,4-D. A curva de crescimento de calos apresenta crescimento tipo sigmóide, com três fases distintas: lag (entre 0 - 42 dias de inoculação), exponencial (42 - 77 dias) e linear (77 84 dias). Não foi observado acúmulo de proteínas em nenhuma fase de crescimento dos calos, sendo o teor máximo de açúcar redutor observado no dia de inoculação do explante. O padrão proteíco observado no período de desenvolvimento de calos apresenta diferenças quantitativas (intensidade das bandas) e qualitativas (presença ou ausência de bandas).

\section{INDUCTION AND BIOCHEMICAL ANALYSIS OF CALLUS FROM LEAF SEGMENTS OF Coffea arabica L., CULTIVAR RUBI}

\begin{abstract}
The objective of this work was to study the effect of 2,4-D and BAP in the induction of callus formation from leaf segments of Coffea arabica L. cv Rubi plantlets obtained through in vitro germination as well as to determine its growth curve, protein pattern and levels of total proteins and reducing sugars. The results indicated that explants inoculated in the absence of growth regulators or in the presence of BAP only showed no callus formation. Maximum callus
\end{abstract}

production is obtained when $1.0 \mathrm{mg} \mathrm{L}^{-1} 2,4-\mathrm{D}$ is used. The callus growth curve showed a sigmoidal shape with 3 distinct phases: lag (0-42 d), exponential (42-77 d) and linear (77-84 d). It was not observed accumulation of proteins in any of the phases of callus growth and maximum levels of reducing sugars were observed in explants at the inoculation day. The callus protein pattern presented quantitative (intensity of bands) and qualitative (presence or absence of bands) differences.

INDEX TERMS: Coffea arabica, callus induction, protein pattern.

\section{INTRODUÇÃO}

A cafeicultura é uma atividade de grande expressão no cenário agroindustrial brasileiro e destaca o Brasil como o maior produtor e maior exportador de café do mundo. Minas Gerais é responsável por $50 \%$ da produção nacional, sendo o sul de
Minas considerado a região mais produtora do estado.

Embora a forma mais utilizada de propagação do cafeeiro seja por meio de mudas obtidas de sementes, a perda do poder germinativo é considerada um dos principais problemas à sua propagação, por dificultar o armazenamento e preservação de estoques genéticos superiores.

\footnotetext{
1. Mestrado em Agronomia/Fisiologia Vegetal, Departamento de Biologia, UNIVERSIDADE FEDERAL DE LAVRAS/UFLA, Caixa Postal 37 - 37200-000 - Lavras, MG, Bolsista de Apoio Técnico à Pesquisa/FAPEMIG.

2. Professor Adjunto, PhD, Departamento de Biologia, UFLA.

3. Professor Adjunto, Dra, Departamento de Agricultura, UFLA

4. Pesquisador III, PhD, Embrapa Milho e Sorgo, Caixa Postal 151, 35701-970 - Sete Lagoas, MG.
} 
Atualmente, técnicas de cultura in vitro de tecidos vegetais têm sido utilizadas com sucesso na multiplicação de espécies que apresentam dificuldade de propagação sexuada. A cultura de calos tem permitido o estabelecimento in vitro, o que, conseqüentemente, proporciona a propagação em larga escala de diversas espécies. No entanto, ainda estão em fase inicial de exploração as possíveis mudanças no tecido vegetal capaz de induzir a formação de calos (Paiva Neto et al., 1997).

Com este trabalho objetivou-se estudar o efeito de 2,4-D e BAP na indução da formação de calos originados de segmentos foliares de plântulas de Coffea arabica L. cv Rubi, determinar sua curva de crescimento e analisar os calos bioquimicamente, mediante teores de proteínas totais, açúcares redutores e padrão protéico.

\section{MATERIAL E MÉTODOS}

\section{Efeito de 2,4-D e BAP na indução de calogê- nese}

Os explantes foram constituídos por segmentos foliares de aproximadamente $0,25 \mathrm{~cm}^{2}$, extraídos de plântulas obtidas pela germinação in vitro de embriões e inoculados em meio de cultura MS 50\% (Murashige \& Skoog, 1962) suplementado com 3\% de sacarose, $0,7 \%$ de agar, adicionando 2,4-D $(0 ; 0,5 ; 1,0 ; 1,5 ; 2,0$; 2,5 e $\left.3,0 \mathrm{mg} \mathrm{L}^{-1}\right)$ e BAP $(0 ; 0,5 ; 1,0 ; 1,5 ; 2,0 ; 2,5$ e 3,0 $\mathrm{mg} \mathrm{L}^{-1}$ ) em todas as combinações possíveis. $\mathrm{O}$ meio de cultura foi ajustado para $\mathrm{pH}$ de 5,6 e autoclavado a $121^{\circ} \mathrm{C}$ por 20 minutos. Após a inoculação, os explantes foram mantidos no escuro, em sala de crescimento, a $25 \pm 1^{\circ} \mathrm{C}$, por um período de 45 dias, quando foi avaliada a área dos explantes cobertas com calos.

\section{Obtenção da curva de crescimento de calos}

Os explantes foram inoculados em tubos de ensaio contendo meio MS 50\%, pH 5,6 suplementado com $3 \%$ de sacarose e $1,0 \mathrm{mg} \mathrm{L}^{-1}$ de $2,4-\mathrm{D}$, sendo mantidos após a inoculação em sala de crescimento, na ausência de luz, sob temperatura de $25 \pm 1{ }^{\circ} \mathrm{C}$. As avaliações da formação de calogênese para fins de obtenção da curva de crescimento foram feitas a partir do dia da inoculação (tempo 0) até o $84^{0}$ dia, com intervalos de coleta de sete dias. Em cada coleta, os calos foram cuidadosamente limpos com papel absorvente e pesados em balança de precisão.

O delineamento estatístico utilizado foi o inteiramente casualizado contendo quatro repetições, cada uma composta por dois tubos de ensaio (um explante/tubo).

\section{Análise bioquímica}

Utilizaram-se intervalos de 21 dias para as coletas de calos (300 mg), durante um período de 84 dias de inoculação. Os calos foram imersos em nitrogênio líquido e armazenados em freezer à temperatura de $-80^{\circ} \mathrm{C}$.

Para a obtenção do extrato enzimático bruto, pesaram-se $300 \mathrm{mg}$ de calos, que foram macerados em almofariz com nitrogênio líquido, adicionando-se 300 ml de tampão de extração (Borato 12,5 mM; pH 10; SDS $1 \%$, $\beta$-mercaptoetanol 2\%, PVPP (100 mg), PMSF $1,0 \mathrm{mM}$ e DTT 2,0 mM). As amostras foram transferidas para microtubos eppendorf de 1,5 mL e centrifugadas a $16.000 \mathrm{~g}$ em microcentrífuga por 20 $\min$ a $4^{\circ} \mathrm{C}$. O sobrenadante foi transferido para outro microtubo, o qual foi armazenado a $4^{\circ} \mathrm{C}$.

\section{Quantificação de proteínas totais e padrão protéico}

A quantificação de proteínas totais foi realizada pelo Método do Ácido Bicinconínico. Para determinar a concentração de proteína total, $2 \mu 1$ do extrato protéico foram diluídos 500 vezes. Adicionaram-se $2 \mathrm{~mL}$ do reagente de determinação de proteína (Solução ácido bicinconínico acrescido de sulfato de cobre, 1:50 v/v). A leitura foi realizada em espectrofotômetro, em comprimento de onda de $562 \mathrm{~nm}$, sendo os valores expressos em $\mu \mathrm{g}$ proteína $\mathrm{g}^{-1}$ de calos, utilizando-se o BSA para a determinação da curva padrão.

Para separação das proteínas em gel de poliacrilamida, adicionoram-se $30 \mu \mathrm{l}$ de corante-tampão da amostra - DYE $(0,2 \%$ de azul de bromofenol (p/v), tris$\mathrm{HCl} 25 \mathrm{mM}$, glicerol 50\%) a $30 \mu \mathrm{l}$ do extrato protéico. Essa solução foi aquecida durante $5 \mathrm{~min}$. antes de ser aplicada ao gel de gradiente de poliacrilamida. Os géis foram preparados em sistema desnaturante descontínuo (Laemmli, 1970) consistindo de dois sistemas: o gel concentrador e o gel separador. O primeiro possuía TRIS, 1,5 M, pH 6,8, SDS $20 \%$ e acrilamida $30 \%$, enquanto o segundo foi constituído de TRIS $0,5 \mathrm{M}, \mathrm{pH}$ 8,8 , SDS $20 \%$ e acrilamida $30 \%$. A separação eletroforética foi realizada em cuba vertical Biorad em tampão de corrida (TRIS 0,5 M; pH 8,8; glicina 1,92 M; pH 8,3 e SDS 0,1\%) com voltagem de $100 \mathrm{~V}$. Aplicaram-se 30 $\mu \mathrm{L}$ de amostra por canaleta de gel para proteína total, num equivalente a $300 \mathrm{mg}$ dos calos macerados. Os

Ciênc. agrotec., Lavras. V.27, n.3, p.571-577, maio/jun., 2003 
géis foram corados com Coomassie Brilliant Blue (Coomassie Brilliant Blue R-250, 0,15\% p/v, etanol 50\%, ácido acético $10 \%$ ) durante 10 horas, sob leve agitação e descorados em solução contendo etanol $5 \%$ e ácido acético $10 \%$, para visualização das bandas. Nesses géis, foram utilizados marcadores de alto peso molecular, com as respectivas faixas de peso molecular de 29 a $205 \mathrm{kD}$.

\section{Quantificação de açúcares redutores}

Para a obtenção do teor de açúcares redutores, foi empregada a metodologia descrita por Miller (1959), utilizando-se ácido 3,5-dinitro-salicílico (DNS). Alíquotas de $500 \mu \mathrm{l}$ do sobrenadante foram adicionadas em 1,0 ml de água destilada e 1,0 $\mathrm{ml}$ do reagente DNS. Essa mistura foi homogeneizada em agitador e colocada em água fervente, por $5 \mathrm{~min}$, sendo, posteriormente, resfriada à temperatura ambiente. Subseqüentemente foram realizadas as leituras, em espectrofotômetro, a $540 \mathrm{~nm}$, sendo a quantificação baseada em curvapadrão para glicose.

\section{RESULTADOS E DISCUSSÃO}

Não foi observada calogênese em explantes inoculados na ausência de 2,4-D e BAP e nos tratamentos apenas com BAP. Indução de calos em resposta à combinação entre BAP e auxinas também são relatadas por Vietez \& San-José (1996). Esses autores também não observaram formação de calos em explantes foliares de faia (Fagus sylvatica L.), quando BAP foi utilizado isoladamente.
O uso isolado da auxina 2,4-D, nas concentrações de $0,5,1,0$ e $1,5 \mathrm{mg} \mathrm{L}^{-1}$, proporcionou, respectivamente, $61 \%$, 67\% e $69 \%$ de produção de calos (Figura 1). Concentrações de 2,4-D superiores a $1,5 \mathrm{mg} \mathrm{L}^{-1}$ inibiram a produção de calos.

Esses resultados estão de acordo com Pasqual et al. (1998), os quais consideram essencial o uso de auxinas em concentrações reduzidas para promover a formação e crescimento de calos.

A interação de 2,4-D e BAP não apresentou efeito significativo na produção de calos, independente das concentrações utilizadas. Esses resultados discordam de Carvalho et al. (1974), que consideram essencial a combinação entre 2,4-D e uma citocinina para a proliferação de calos de explantes foliares e nodais de cafeeiro. Resultado contrário também foi encontrado por Cunha \& Ferreira (1996), os quais observaram a necessidade de interação entre auxina e citocinina para a eficiente indução de calos em explantes de alcea rosa (Linum usitatissimum L).

O padrão de crescimento de calos formados a partir de segmentos foliares de Coffea arabica cv Rubi está apresentado na Figura 2.

Observou-se crescimento sigmoidal, com tendência de ganho de matéria fresca em função do aumento do tempo de cultivo. No período analisado (84 dias de cultivo), foi observada a presença de três fases de crescimento distintas (lag, exponencial e linear), não sendo detectada a presença das fases de desaceleração e estacionária, devido à baixa velocidade de crescimento dos calos dessa cultivar.

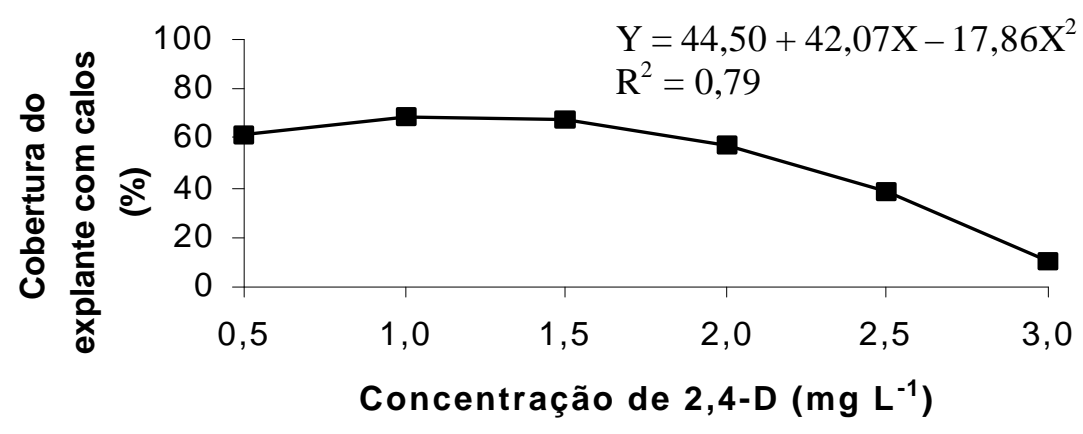

FIGURA 1 - Efeito de diferentes concentrações de 2,4-D, sobre a produção de calos, formados a partir de segmentos foliares de Coffea arabica cv Rubi. 


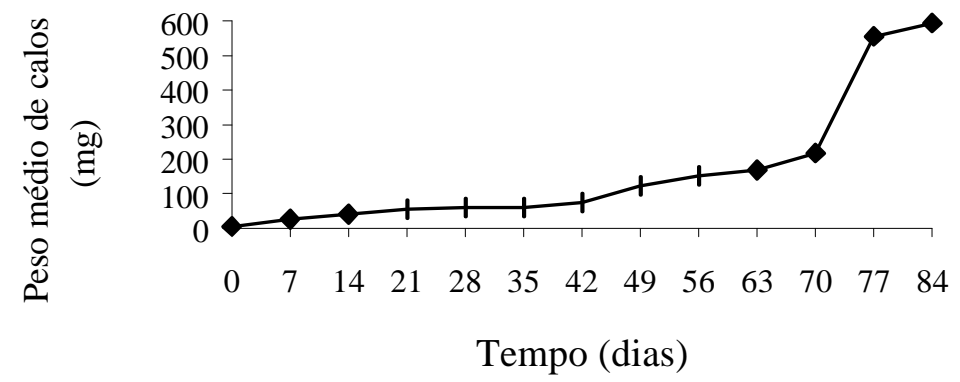

FIGURA 2 - Curva de crescimento de calos formados a partir de segmentos foliares de Coffea arabica cv Rubi inoculados em meio MS suplementado com 1,0 $\mathrm{mg} \mathrm{L}^{-1}$ de 2,4-D.

A fase lag, na qual células do explante preparam-se para a divisão celular, acumulando biomassa, ocorreu até o $42^{0}$ dia de inoculação, apresentado um percentual de crescimento de $66 \%$. Vários estudos têm demonstrado que o período da fase lag varia de acordo com a espécie estudada. Landa et al. (2000) verificaram que para calos obtidos a partir de segmentos foliares de pequizeiro (Caryocar brasiliense Camb), a fase lag ocorre até o $7^{0}$ dia de cultivo. Mezzetti et al. (1991), no entanto, observaram a ocorrência dessa fase até o $30^{0}$ dia após a inoculação de segmentos foliares de kiwi (Actinidia deliciosa (A. Chev.) C. F. Liang e A. R. Ferguson).

A fase de crescimento exponencial, período em que ocorre máxima divisão celular, ocorreu do $42^{\underline{0}}$ até o $77^{0}$ dia de cultivo, apresentando o maior percentual de crescimento de calos (87\%). Deccetti (2000) observou ocorrência dessa fase entre o $16^{0}$ e o $35^{0}$ dia de cultivo em calos de segmentos foliares de Annona glabra L. Em calos de segmentos foliares de pequizeiro, essa fase foi observada entre o $7^{\underline{0}}$ e o $35^{\underline{0}}$ dia de cultivo (Landa et al., 2000).

O período de crescimento linear, em que os calos diminuem a divisão celular e aumentam a área celular, foi observado entre o $77^{0}$ e o $84^{-}$dia de cultivo, apresentando apenas $6 \%$ de crescimento. Santos et al. (1997) observaram essa fase entre o $18^{0}$ e o $26^{0}$ dia de cultivo de explantes foliares de japecanga (Smilax japecanga Griseb).

Os resultados obtidos com a curva de crescimento de calos de explantes foliares de Coffea arabica cv Rubi indicam a ocorrência de crescimento lento, possivelmente devido a um ciclo celular também lento. Estudos mais elaborados de citogenética devem ser feitos, a fim de fornecer informações sobre essa divisão lenta observada.

Observa-se que os teores de proteínas totais ( $\mathrm{Fi}$ gura 3) de calos originados a partir de segmentos foliares mantiveram-se constantes e em baixas concentrações durante o período de cultivo (84 dias).

Esses resultados contradizem Serra et al. (2000), os quais observaram um acúmulo nos teores de proteínas em calos obtidos a partir de explantes foliares de castanheira-do-Brasil (Bertholletia excelsa H.B.K.), até o $30^{-}$dia de cultivo. Esse aumento inicial e posterior redução no teor de proteína também foram detectados por Sacchi et al. (1995) em calos de segmentos foliares de kiwi. $\mu$

A análise de açúcares redutores indicou uma redução dos teores após a inoculação dos explantes até o $21^{\underline{0}}$ dia de cultivo (Figura 4 ).

Redução nos teores de açúcares redutores após a inoculação também foi observada por Paiva Neto (1996) em segmentos foliares de moreira (Chlorophora tinctoria (L.) Gaudichand) cultivados em meio MS acrescido de 2,4-D. Os resultados desse estudo indicaram uma redução nos teores de açúcares redutores, no período que sucedeu a inoculação, seguido de um aumento até 12 dias após a inoculação, e posterior redução até o $30^{0}$ dia de cultivo. Serra et al. (2000), estudando calos originados de segmentos foliares de castanha-do-Brasil, também verificaram redução nos teores de açúcares redutores, após a inoculação dos explantes.

O padrão protéico observado no período de desenvolvimento de calos de segmentos foliares de Coffea arabica cv Rubi apresenta diferenças quantitativas (intensidade das bandas) e qualitativas (presença ou ausência de bandas) (Figura 5). 


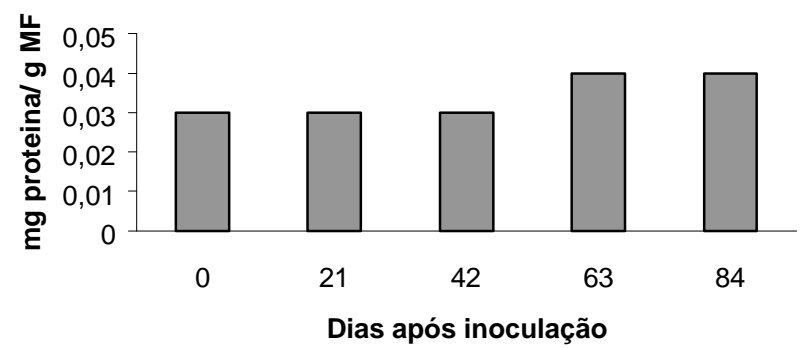

FIGURA 3 - Teores de proteínas totais de calos de segmentos foliares de Coffea arabica cv Rubi inoculados em meio MS, suplementado com $1,0 \mathrm{mg} \mathrm{L}^{-1}$ de 2,4-D.

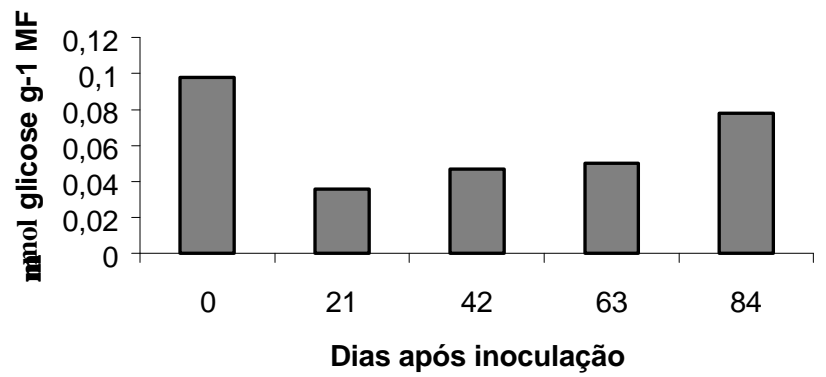

FIGURA 4 - Teores de açúcares redutores de calos de segmentos foliares de Coffea arabica cv Rubi, inoculados em meio MS, suplementado com 1,0 $\mathrm{mg} \mathrm{L}^{-1}$ de 2,4-D.

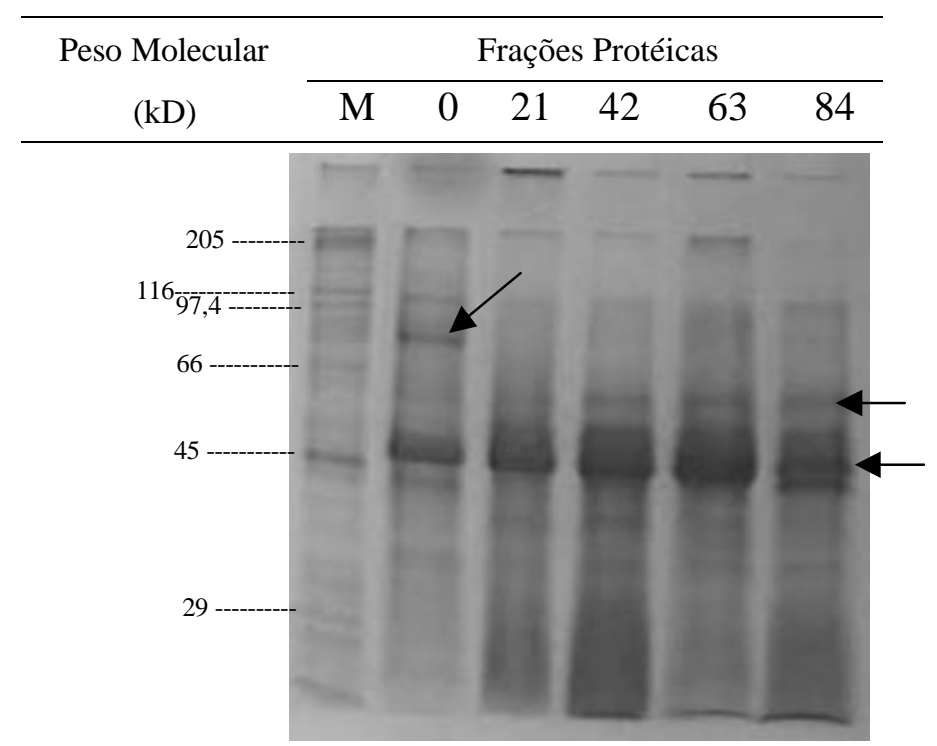

FIGURA 5 - Padrão protéico de calos de segmentos foliares de Coffea arabica cv Rubi inoculados em meio MS suplementado com 1,0 $\mathrm{mg} \mathrm{L}^{-1}$ de 2,4-D. ( $\mathrm{M}$ - marcador molecular). 
Durante todo o período de crescimento dos calos, foi observada a presença de polipeptídeos entre 29 e $66 \mathrm{kD}$. A presença de polipeptídeos de $85 \mathrm{kD}$ foi detectada apenas no dia da inoculação.

Polipeptídeos com peso molecular de $60 \mathrm{kD}$ foram observadas durante toda a fase de crescimento dos calos; porém, até os 21 dias de cultivo, a intensidade foi baixa, período esse pertencente à fase lag do crescimento de calos. Com 42 dias de cultivo, início da fase de crescimento exponencial, a banda de $60 \mathrm{kD}$ apresentou um aumento na intensidade. Polipeptídeos de peso molecular de $45 \mathrm{kD}$ também foram observados com grande intensidade durante todo o período de crescimento de calos.

Embora tenha sido possível determinar o padrão protéico de calos de tecidos foliares de Coffea arabica cv Rubi, a função dos polipeptídeos observados é desconhecida. Além disso, não foram encontradas na literatura referências que relatem o padrão protéico de calos de outras espécies.

\section{CONCLUSÕES}

O uso de concentrações de 2,4-D inferiores a 1,5 $\mathrm{mg} \mathrm{L}^{-1}$ induz à formação de calos em segmentos foliares de Coffea arabica L. cv Rubi.

A curva de crescimento de calos apresentou crescimento sigmoidal, com três fases distintas: lag, exponencial e linear.

Foi determinado o padrão protéico dos calos durante as fases de crescimento.

\section{REFERÊNCIAS BIBLIOGRÁFICAS}

CARVAlHO, F. J. P. C.; CARVAlho, P. C. T.; CRÓCOMO, O. J. Cultura de tecidos de explantes de café. In: CONGRESSO BRASILEIRO DE PESQUISAS CAFEEIRAS, 1974, Poços de Caldas. Resumos... Rio de Janeiro: [s.n.], 1974. v. 2, p. 299300.

CUNHA, A. C. G.; FERREIRA, M. F. Somatic embryogenesis, organogenesis and callus growth kinetics of flax. Plant Cell, Tissue and Organ Culture, Dordrechet, v. 47, p. 1-8, 1996.

DECCETTI, S. F. C. Propagação in vitro de Annona glabra L. 2000. 101 p. Dissertação (Mestrado em Fisiologia Vegetal) - Universidade Federal de Lavras, Lavras.
LAEMMLI, U. K. Cleavage of structural protein during assembly of the head of bacteriophage T4. Nature, London, v. 227, n. 5259, p. 680-684, 1970.

LANDA, F. S. L.; PAIVA, R.; PAIVA, P. D. O.; BUENO FILHO, J. S. S. Indução in vitro de calos em explantes foliares de pequizeiro (Caryocar brasiliense Camb.). Ciência e Agrotecnologia, Lavras, v. 24, p. 56-63, 2000. Edição Especial.

MEZZETTI, B.; CONTE, L. S.; ROSATI, P. Actinidia deliciosa in vitro: II. Growth and exogenous carbohydrates utilization by explants. Plant Cell, Tissue and Organ Culture, Dordrechet, v. 26, p. 153-160, 1991.

MILLER, G. L. Use of dinitrosalicilic acid reagent for determination of reducing sugar. Analytical Biochemistry, New York, v. 31, p. 426-428, 1959.

MURASHIGE, T.; SKOOG, F. A revised medium for rapid growth and bioassays with tobacco tissue cultures. Physiologia Plantarum, Copenhagen, v. 15, p. 473479, 1962.

PAIVA NETO, V. B. Comportamento in vitro de tecido foliar e segmento nodal de moreira (Chlorophora tinctoria (L.) Gaudichaud). 1996. 33 p. Dissertação (Mestrado em Fisiologia Vegetal) - Universidade Federal de Lavras, Lavras.

PAIVA NETO, V. B.; PAIVA, R.; GOMES, G. A. C.; PÓVOA, J. S. R. Comportamento in vitro de segmento nodal de moreira (Chlorophora tinctoria (L.) Gaudichaud). Arquivos de Biologia e Tecnologia, Curitiba, v. 40, n. 1, p. 135-141, mar. 1997.

PASQUAL, M.; RAMOS, J. D.; HOFFMANN, A.; CARVALHO, G. R. Meios de Cultura. In: Curso de pós-graduação Lato sensu (especialização) à distância: cultura de tecidos vegetais: tecnologia e aplicações. Lavras: UFLA/FAEPE, 1998. 127 p.

SACCHI, G. A.; MORGUTTI, S.; ABRUZZESE, A.; ALISI, C.; COCUCCI, M.; ESPEN, L.; LEVA, A. R.; MULEO, R.; NEGRINI, N.; COCUCCI, S. M. Changes in some physiological and biochemical parameters during two subcultures in kiwi (Actinidia deliciosa) callus. Plant Science, Shannon, v. 106, n. 1, p. 107-113, Mar. 1995. 
SANTOS, M. R. A.; PAIVA, R.; BENDADIS, A. K. Cultura de tecidos de Smilax japecanga Grisebach: indução e crescimento de calos. Ciência Agronômica, Fortaleza, v. 28, p. 37-43, 1997.

SERRA, A. G. P.; PAIVA, R.; PAIVA, P. D. O. Análises bioquímicas de calos formados de explantes foliares de castanha-do-Brasil (Bertholletia excelsa H.B.K.).
Ciência e Agrotecnologia, Lavras, v. 24, n. 40, p. 833840, 2000.

VIETEZ, A. M.; SAN-JOSÉ, M. C. Adventitious shoot regeneration from Fagus sylvatica leaf explants in vitro. In Vitro Cellular \& Developmental Biology-Plant, Wallingford, v. 32, p. 140-147, Jul./Sept. 1996. 